\title{
PERTUMBUHAN DAN PERKEMBANGAN ISLAM DI BARRU
}

\author{
Idham \\ Balai Penelitian dan Pengembangan Agama Makassar \\ idbodi@yahoo.co.id
}

\begin{abstract}
Barru is a composite of several kingdoms in ancient times. In the days of the Dutch East Indies, the region is included in the section Pare-Pare. In the early days of independence, this district is the autonomous region which is the former Selfbestuur four, namely: 1) Selfbestuur Mallusetasi, 2) former Selfbestuur Soppeng Riaja, 3) former selfbestuur Barru, and 4) the former Selfbestuur Tanete. This study aims to explore the kingdoms that exist in Barru in the past, the relationship with the royal kingdom of Gowa-Tallo, and reveal the growth and development of Islam in Barru (in this case the royal Tanete). This study uses historical method, which explains the issue from the perspective of historical research. The findings showed that there were several kingdoms in the past in Barru (ie the Kingdom Tanete, Berru, Soppeng Riaja, and Nepo. Barru entry of Islam in the past is the role of the Kingdom of Gowa-Tallo. Pioneer as for the spread of Islam in Barru in the early period of Islam is king La Ponci known as Petta SugiE or PalaselaseE Petta (1603-1625) who is assisted by a scholar named Daeng Matepu.
\end{abstract}

Keywords: Islamization; Barru; Tanete, Berru, Soppeng Riaja, and Mallusetasi.

\begin{abstract}
ABSTRAK
Kabupaten Barru adalah gabungan beberapa kerajaan pada zaman dahulu. Pada zaman Hindia Belanda, wilayah ini termasuk dalam wilayah afdeling Parepare. Di awal kemerdekaan, kabupaten ini adalah wilayah swapraja yang merupakan empat bekas Selfbestuur, yakni: Selfbestuur Mallusetasi, bekas Selfbestuur Soppeng Riaja, bekas selfbestuur Barru, dan bekas Selfbestuur Tanete. Tulisan ini bertujuan untuk menelusuri kerajaan-kerajaan yang ada di Kabupaten Barru pada masa lampau, hubungan kerajaan tersebut dengan kerajaan Gowa-Tallo, dan mengungkap pertumbuhan dan perkembangan Agama Islam di Kabupaten Barru (dalam hal ini kerajaan Tanete). Kajian ini menggunakan metode sejarah (metode historis), yang menjelaskan persoalan penelitian berdasarkan perspektif sejarah. Hasil kajian menunjukkan bahwa terdapat beberapa kerajaan pada masa lampau di Kabupaten Barru (yakni Kerajaan Tanete, Berru, Soppeng Riaja, dan Nepo. Masuknya Islam di Kabupaten Barru pada masa lampau tidak lepas dari peranan Kerajaan Gowa-Tallo. Adapun yang menjadi pioneer penyebaran Islam di Kabupaten Barru pada Masa awal masuknya Islam adalah raja La Ponci yang dikenal dengan nama Petta SugiE atau Petta Palase-laseE (1603-1625) yang dibantu oleh seorang ulama yang bernama Daeng Matepu.
\end{abstract}

Kata kunci: Islamisasi; Barru; Kerajaan Tanete, Berru, Soppeng Riaja, Mallusetasi.

historiografi Islam pada periode perlawanan terhadap kolonialisme, (3) historiografi Islam periode awal abad ke-20 dan pergerakan nasional, dan (4) historiografi Islam periode kontemporer dan memoir (Umar, 1985: 106).

Merujuk periodesasi penulisan

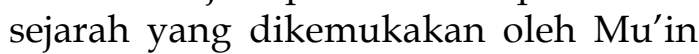


Umar di atas, maka penelitian ini memfokuskan pada historiografi Islam periode awal masuknya agama Islam di Tanete Kabupaten Barru. Hal ini penting dilakukan karena selama ini, bangsa Indonesia berupaya membangun dan mengembangkan kebudayaan nasional untuk dijadikan sebagai rumah besar tempat berkumpulnya puncak-puncak kebudayaan daerah. Pola pembinaan yang dilakukan melalui bentuk-bentuk penyeragaman yang top-down. Akibatnya, sebagian besar kebijakan yang ditempuh hanya menghancurkan rumah-rumah kecil kebudayaan, tempat bermukimnya kebudayaan daerah. Rumah-rumah kecil tersebut, berisi berbagai kearifan dan pengetahuan tradisional bangsa yang terakumulasi dan terekspresi dalam berbagai budaya setempat. Di dalam karya-karya tersebut terdapat tatanan tradisional yang merupakan saksi zaman dan tersimpan berbagai ingatan kultural serta ingatan zaman dari suku bangsa yang bersangkutan. Setiap manusia Indonesia telah dibesarkan dan disosialisasi melalui rumah-rumah kebudayaan kecil mereka berupa nilai-nilai yang tertanam dalam dirinya (Nurhayati Rahman, 1999).

Pada saat rumah besar tersebut mengalami krisis, seperti yang dialami bangsa kita, dilihat dari gejala sosial dan kebudayaan, masyarakat Indonesia tibatiba menjadi anomaly dan kehilangan keseimbangan, ibarat kehilangan rumah -rumah kecil mereka, tempat mereka dibesarkan. Akibatnya, masyarakat menjadi emosional dan mudah histeria. Bersamaan dengan itu, reformasi pun telah bergulir, keran-keran demokrasi terbuka dengan lebar, ironisnya yang terjadi justru demokrasi diterjemahkan tanpa batas, tanpa hukum, yang berimplikasi pada ancaman perpecahan dan disintegrasi bangsa (Idham, 2012). Di sinilah pentingnya rumah-rumah kecil atau sejarah lokal diaktualisasilkan kembali demi kewibawaan sebuah rumah besar, bangsa Indonesia.

Sejarah lokal berarti sejarah dari suatu tempat, suatu locality, yang batasan geografisnya dapat suatu tempat tinggal suku bangsa, yang kini mungkin telah mencakup dua-tiga daerah administratif, dan juga dapat pula suatu kota, atau malahan suatu desa. Dengan demikian, sejarah lokal secara sederhana dirumuskan sebagai kisah di kelampauan dari kelompok-kelompok masyarakat yang berada pada daerah geografis yang terbatas. Penekanannya adalah ruang lingkup geografis, bukan problem teoritis-filosofis (Abdullah, 1985: 15).

Sejarah lokal adalah "asal usul, pertumbuhan, kemunduran dan kejatuhan dari kelompok masyarakat lokal. Walaupun tidak berarti bahwa dan tidak ada maksud untuk menunggu "kemunduran" dan "kejatuhan" bangsa atau masyarakat lokal itu. Secara garis besar corak studi sejarah lokal yang pernah dilakukan tentang Indonesia dapat dibedakan atas empat golongan, yaitu: (1) studi yang difokuskan pada suatu peristiwa tertentu (studi peristiwa khusus atau apa yang disebut evenemental); (2) studi yang menekankan pada struktur; (3) studi yang mengambil perkembangan aspek tertentu dalam kurun waktu tertentu pula (studi tematis), dan (4) studi sejarah umum, yang menguraikan perkembangan daerah tertentu (provinsi, kota, kabupaten) dari masa ke masa (Abdullah, 1990: 18 dan 26).

Sejarah lokal Indonesia selalu dihubungkan dengan sejarah kerajaankerajaan yang pernah ada dan eksis di Nusantara ini yang belakangan disebut Indonesia. Indonesia sesungguhnya adalah kata politik untuk mengikat pulau-pulau yang terbentang dari Sabang sampai Merauke. Pulau-pulau yang ter- 
bentang luas itu sebelum menjadi satu kesatuan Negara Republik Indonesia, merupakan bekas wilayah yang disebut Hindia Belanda dibawah kekuasaan Belanda. Proses pembentukan kehidupan kenegaraan itu pada kenyataannya merupakan wujud dari perjuangan rakyat yang berlangsung melalui proses sejarah yang panjang. Perjuangan rakyat Indonesia dalam perkembangannya mencapai titik puncak setelah Perang Dunia II, yaitu dengan diproklamasikannya kemerdekaan Indonesia (Sahajuddin, 2009: 1). Pertanyaan kemudian, faktor apakah yang meneguhkan sikap patriotisme dan nasionalisme tersebut? Banyak pendapat dalam hal ini, ada yang mengatakan karena faktor senasib, sama-sama menderita dalam sebuah penjajahan, sama-sama jajahan kompeni Belanda, ada pula yang berpendapat bahwa nasionalisme itu lebih karena diikat oleh sebuah ideologi keagamaan, yakni agama Islam. Tentu, dalam ruang ini bukan untuk mempertentangkan, faktor mana yang paling dominan. Namun yang ingin dibahas dalam tulisan ini adalah, bagaimana rumah-rumah kecil atau kerajaan-kerajaan lokal itu berislam, salah satu kerajaan itu adalah kerajaan yang ada di Kabupaten Barru, provinsi Sulwesi Selatan.

Permasalahan pokok dalam kajian iti adalah bagaimana historiografi Islam periode awal masuknya Islam di Kabupaten Barru? Dari permasalahan pokok tersebut, ada tiga tertanyaan penelitian yang ingin dijawab, yakni: (1) KerajaanKerajaan apa saja yang pernah eksis di Kabupaten Barru pada masa lampau? (2) Bagaimana hubungan kerajaankerajaan tersebut (khususnya kerajaan Tanete) dengan kerajaan Gowa-Tallo yang pertama kali menerima Islam? dan (3) siapa yang menjadi pionir penyebar agama Islam pada periode awal masuknya Islam di Kabupaten Barru?

Untuk menjawab permasalahan pokok dalam kajian ini, digunakan metode sejarah (metode historis). Prosedurnya meliputi empat tahapan, yaitu pencarian dan pengumpulan sumber (heuristic), kritik sumber (seleksi data), interpretasi (penafsiran), dan penyajian atau penulisan sejarah (historiografi).

\section{SEJARAH KAREJAAN TANETE}

Pada awalnya, sekitar abad ke-15, daerah ini bernama Pujananti, kemudian berubah menjadi Agangnionjo dan akhirnya bernama Tanete pada sekitar abad ke-17 (Koro, 2005: 19). Disebut Agangnionjo karena letaknya strategis dan selalu dilewati orang dari daerah lain. Jalan ini dalam bahasa Makassar (agang) dilewati (nionjo). Kerajaan Agangnionjo adalah salah satu kerajaan yang baru terbentuk setelah To Sangiang memohon Karaeng Sigeri untuk berperan pula menjadi raja Agangnionjo. Kesediaan Karaeng Sigeri memenuhi permohonan tersebut tampak tidak berdampak pada penyatuan dua wilayah pemerintahan itu dibawah kepemimpinan seorang raja, tetapi tetap menempatkan dua wilayah pemerintahahnitu tetap terpisah dan masigmasing berkedudukan kerajaan yang merdeka dan berdaulat. Kedudukan ini berbeda dengan kedudukan kerajaan Makassar yang terbentuk melalui kesepakatan yang dicapai untuk mengakhiri perang antara Kerajaan Gowa dengan kerajaan Tallo yang terjadi pada tahun 1528. Dua kerajaan itu membentuk satu kesatuan yang kemudian lazim dikenal kerajaan Makassar dengan ungkapan "satu rakyat tetapi dua raja (sereji ata narua karaeng) (Poelinggomang, 2002: 2425). Raja Gowa menjadi raja Kerajaan Makassar dan Raja Tallo menjadi Mangkubumi (Tumabicara Butta) kerajaan Makassar. Ungkapan yang dapat 
digunakan untuk mengungkapkan hubungan antara kerajaan Agangnionjo dengan kerajaan Segeri adalah "seorang Raja tetapi dua Rakyat" (Sereji karaeng narua ata) (Poelinggomang, 2005: 29).

Ponobatan Karaeng Sigeri menjadi raja Agangnionjo berkaitan dengan darah kebangsawannnya. Ia berasal dari strata bangsawan keturunan Tumanurung di Gowa (ana karaeng ri Gowa) putera dari saudara perempuan Karaeng Tunipallangga Ulaweng (Poelinggomang, 2005: 29). Penobatan menjadi raja Agangnionjo secara tidak langsung merupakan pengabsahan jalinan hubungan antara kerajaan ini dengan Kerajaan Makassar. Jalinan hubungan antara dua kerajaan itu menjadi dasar sehingga Kerajaan Agangnionjo juga berpikir bertanggung jawab untuk melindungi dan membantu Kerajaan Makassar.

Sebagaimana telah disebutkan di atas, bahwa kerajaan ini beberapa kali berganti nama, awalnya Pujananti menjadi kerajaan agangnionjo. Pada masa pemerintahan Tumaburu Limanna (1597 -1603) kerajaan ini berubah nama menjadi Kerajaan Tanete sebagai wujud persaudaraannya dengan kerajaan Tanete (Selayar) (Nurhayati Rahman, 2008: 54). Konon, pada suatu konjungan ke Somba Opu (ibukota kerajaan Makassar), dating pula Opu Tanete (Selayar) menghadap Raja Makassar yang menyamnpaikan bahwa ia datang membawa duni (peti mayat) yang berisi jenazah putera Raja Luwu yang bernama LasoE, yang mati terdampar akibat perahu dagangnya tenggelam di perairan Selayar. Sehubungan dengan itu, Raja Makassar memohon kepada Tomaburu Limanna kiranya bersedia menemani Opu Tanete bersama pengiring jenazahnya untuk mengantar jenazah itu. Permohonan itu merupakan suatu kehormatan sehingga pada hari itu juga peti jenazah dimuat para perahu Raja gangnionjo dan berangkat bersama Opu Tanete ke Luwu untuk memperkuat dan saling mengingat di antara kedua kerajaan pengantar jenazah tersebut, maka kerajaan Agangnionjo mengganti nama kerajaannya dengan nama Tanete, sama dengan nama Tanete yang ada di Selayar.

Edward L. Poelinggomang (2005) kurang sependapat dengan pendapat ini, ia berpendapat bahwa dalam merancang pengusungan jenazah itu dicapai kesepakatan untuk menetapkan iring-iringan itu adalah iring-iringan kerajaan Tanate, meskipun dikawal oleh raja Agangnionjo dan Opu Tanete (Selayar) tampaknya dua pengiring dengan satu nama itu menumbuhkan rasa persaudaraan diantara mereka. Oleh karena itu, sekembali dari Luwu, dua raja itu berikrar membentuk persekutan dan persaudaraan yang isi pokoknya adalah “jika rakyat Agangnionjo bepergian ke Tanete (Selayar) maka ia menjadi orang Tanete, demikian pula sebaliknya". Juga bila armada Agangnionjo berada di peraoran Tanete (Selayar), walaupun dalam keadaan tergesah-gesah, wajib singgah walaupun hanya sejenak, demikian pula sebaliknya. Ikrar itu menjadi konvensi, dimana ikataran persaudaraan kedua kerajaan itu demikian erat sehingga kerajaan Agangnionjo juga diidentifikasikan sebagai kerajaan Tanete (Pelinggomang, 2005).

\section{AWAL MULA ISLAM DI SULAWESI SELATAN}

\section{Gowa-Tallo: Penerima dan Penyiar Is- lam di Sulawesi Selatan}

Masuknya Islam di Sulawesi Selatan, khususnya Gowa, telah banyak ditulis oleh sejarawan. Sulawesi Selatan yang dalam hal ini diwakili Gowa, me- 
mang tidak dapat dinapikan, karena kerajaan kembar Gowa-Tallo lah yang mula menerima agama ini. Agama Islam masuk dan berkembang di Sulawesi selatan pada awal abad ke-17 yang dibawa oleh tiga orang ulama besar yaitu: Abdul Makmur Khatib Tunggal (Dato ri Bandang) Khatib Sulaiman (Datuk Pattimang) dan Khatib Bungsu (Dato Ri Tiro). Ketiganya berasal dari Minangkabau, Sumatera Barat. Beliau bertiga kemudian membagi diri pada tiga daerah utama yang akan dijadikan sebagai pusat penyebaran Islam yaitu; Kerajaan Gowa-Tallo oleh Datuk ri Bandang (Khatib Tunggal), yang menyebarkan agama Islam dengan jalan tasauf. Di Kerajaan Luwu oleh Datu Patimang, atau Khatib Sulaiman, mengajarkan dan menyebarkan agama Islam dan berhasil mengislamkan Payungnge ri Luwu yang bernama La Pattiware Daeng Parabbung, dengan gelar Arabnya Sultan Muhammad, dan setelah baginda wafat digelar "MatinroE ri Ware" (Daeng Patunru, 1969: 19).

Tiga mubaligh ini pada awalnya mengunjungi Kerajaan Luwu dan mengislamkan raja dan rakyat kerajaan itu. Setelah itu mulai menyiarkan ke kerajaan lain termasuk Kerajaan GowaTallo. Walaupun Islam telah menjadi agama umum di Kerajaan Luwu (1603), atau lebih dahulu daripada Kerajaan Gowa-Tallo menjadi kerajaan Islam (1605), namun kerajaan ini jugalah yang menjadi pusat penyebaran agama Islam untuk seluruh jazirah Sulawesi Selatan. Jadi, tidak mengherankan kalau politik pengislaman seluruh Sulawesi Selatan dijalankan oleh raja Gowa-Tallo dengan sangat kuatnya. Keadaan itu dilandaskan pada satu perjanjian yang pernah disepakati terdahulu antara Kerajaan Gowa-Tallo dan beberapa kerajaan lainnya yang ada di Sulawesi Selatan. Isi perjanjian itu antara lain berbunyi: "... bahwa barang siapa menemukan jalan yang lebih baik, maka ia berjanji akan memberitahukan tentang jalan yang lebih baik itu kepada raja-raja sekutunya" (Mattulada, 1976).

Raja yang memeluk agama Islam pada saat itu adalah raja Tallo yang juga merupakan Mangkubumi Kerajaan Gowa-Tallo yaitu I Malingkaang Daeng Manyonri dan setelah memeluk agama Islam, beliau digelar Sultan Abdullah Awalul Islam. Setelah beliau masuk Islam, maka diikuti pula oleh Raja Gowa I Mangngarangi Daeng Marabbia yang kemudian seluruh rakyat GowaTallo dinyatakan telah menerima agama Islam yang dibuktikan dengan melakukan salat Jumat untuk pertama kalinya di Tallo pada tanggal 9 November 1607 masehi atau bertepatan dengan tanggal 18 Rajab 1016 Hijriah (Mattulada, 1999: 51). Yang mengislamkan kedua raja tersebut, adalah salah satu dari ketiga orang ulama tersebut di atas (Khatib Tunggal Abdul Makmur) yang kemudian lazim dikenal sebagai Datu Ri Bandang.

Agama Islam di Sulawesi Selatan, khususnya Kerajaan Gowa-Tallo, setidaknya telah masuk pada masa pemerintahan Raja Gowa X Tunipalangga yang memerintah antara tahun 15461565. Faktanya dapat diketahui karena raja Gowa ketika itu telah memberikan izin kepada para pedagang Melayu dengan perantaraan Anakoda Bonang untuk menetap di Mangaalekkana dan telah mendirikan masjid pada masa itu, dan merupakan yang pertama di Sulawesi Selatan (Mappangara, dkk. 2003: 4). Sewaktu I Manggorai Daeng Mammate menjadi Raja Gowa XII (15651590), Raja Ternate Baabullah tiba di Makassar pada tahun 1580, setelah mengadakan safari peperangan yang mengalahkan Banggai, Buton dan Selayar. Selanjutnya Baabullah mengadakan perjanjian persahabatan dengan Raja Gowa saat itu dan menyerahkan Se- 
layar sebagai tanda sahnya persahabatan. Raja Ternate ini berhasrat menyebarkan Islam di Sulawesi Selatan terutama kepada orang-orang Melayu yang berada di Makassar, dimana Islam di sana belum banyak pengikutnya (Koro, 2005: 19).

Melihat kenyataan itu, bahwa ada jarak waktu yang sangat panjang antara kehadiran pedagang orang-orang Melayu yang berdiam di Mangalekkana dengan diterimanya agama Islam sebagai agama resmi Kerajaan GowaTallo, justru terjadi pada awal abad ke17 (1603). Angka tahun ini diambil dari Lontarak Bilang Gowa-Tallo (buku harian Kerajaan Gowa-Tallo) yang menyatakan bahwa: "pada tanggal 22 September 1603, atau bertepatan dengan tanggang 9 Jumadil Awal 1015 Hijriah, malam Jumat, kedua raja bersaudara itu memeluk agama Islam" (Kamaruddin, dkk. 1986: 9). Pendapat ini dibantah oleh Noorduyn dan menyatakan bahwa apa yang ditulis dalam Lontarak Bilang Gowa-Tallo itu, adalah kesalahan penulisan karena yang benar adalah: Hari Kamis 22 September 1605, bertepatan pada tanggal 9 Jumadil Awal 1014 Hijriah" (Noordyun, 1972: 3).

Setelah raja dan Mangkubumi menganut ajaran Islam, langkah selanjutnya adalah bergiat mengislamkan seluruh rakyatnya. Ketekunan usaha Khatib Tunggal dan penguasa kerajaan akhirnya dalam waktu dua tahun (1607) rakyat kerajaan itu berhasil diislamkan. Keberhasilan itu menghantar penguasa kerajaan ini menyelenggarakan sholat Jumat bersama dengan seluruh pejabat kerajaan dan rakyat di Tallo pada tanggal 9 November 1607. Shalat bersama ini merupakan upacara ritual yang menempatkan kerajaan ini menjadi kerajaan Islam, atau dengan kata lain shalat itu sebagai bukti bahwa Kerajaan GowaTallo telah beralih dari dunia kafir (daar al harb) menjadi dunia Islam (daar al Is- lam) (Poelinggomang, 2005: 45-46; Sahajuddin, 2010: 101-112).

Setelah pengabsahan dan pengesahan kedudukan kerajaan menjadi Kerajaan Islam, maka langkah selanjutnya adalah bergiat menyiarkan Islam kepada kerajaan-kerajaan sekutu lainnya. Rencana itu dilaksanakan berdasarkan kesepakatan sebelumnya dengan kerajaan-kerajaan sekutu lainnya seperti Bone, Wajo, Soppeng, termasuk kerajaan Tanete, dan kerajaan lainnya, "bahwa barang siapa yang menemukan jalan yang lebih baik harus memberitahukan penguasa kerajaan lainnya yang ikut terlibat dalam perjanjian ini". Hal itu menjadi dasar penguasa Kerajaan Gowa-Tallo memandang wajib menyerukan kepada kerajaan sekutunya untuk menerima ajaran Islam yang dipandang sebagai ajaran yang mulia, baik, dan benar.

\section{Tanete Menerima Islam}

Peranan Kerajaan Gowa-Tallo dalam proses islamisasi yang mengintroduksikan kepada kerajaan lain pada awal abad XVII tidak bisa dipungkiri lagi. Proses islamisasi ini pulalah yang memperuncing pergolakan politik antar kerajaan-kerajaan di Sulawesi Selatan. Awal abad XVII perkembangan politik di Sulawesi Selatan dengan perang antar kerajaan memperoleh dimensi berkonfrontasi, kemudian ditambah dengan faktor agama Islam. Setelah Karaeng Matoaya mengikuti jejak Sultan Alauddin memeluk agama Islam, maka Gowa selaku Perintis berusaha mengintroduksikan agama Islam di kerajaan-kerajaan lain, kecuali Luwu yang telah masuk Islam terlebih dahulu, bila perlu memeranginya (Kartodirdjo, 1988: 89-90). Dengan demikian, maka proses islamisasi di Kerajaan Tanete juga terkait dengan rancangan pemerintah Kerajaan Gowa-Tallo yang menempat- 
kan kerajaannya menjadi pusat syiar Islam di Sulawesi Selatan yang dilaksanakan oleh para mubaligh Islam Minangkabau yang datang dari Aceh, yaitu Abdul Makmur Khatib Tunggal Dato Ibdah yang lebih dikenal dengan nama Dato ri Bandang, Sulaiman Khatib Sulung yang lebih dikenal nama Dato Patimang, dan Abdul Jawad Khatib Bungsu yang lebih dikenal dengan nama Dato ri Tiro (Poelinggomang, dkk. 2004: 45).

Sementara penerimaan Islam di Kerajaan Tanete secara resmi terjadi pada tahun 1608 setelah utusan Kerajaan Gowa datang ke raja Tanete menyampaikan pesan raja Gowa agar raja Tanete datang ke Sombaopu untuk menerima agama Islam. Raja Tanete yang saat itu adalah Petta Palase LaseE (1603-1625). Setelah utusan raja Gowa menyampaikan pesan itu, raja Tanete sangat gembira karena hasrat raja Tanete untuk masuk Islam telah lama. Jadi proses masuknya Islam di Tanete sangat muda dengan beberapa alasan, diantaranya: Peng-Islam-an raja Tanete berlangsung di Makassar, Seruan untuk menganut agama Islam tersebut diterima dengan senang hati, Raja Tanete bersedia menyiarkan dan mengajak rakyatnya menerima Islam, dan raja Tanete mengemban tugas menyiarkan dan mengajak raja Nepo dan lainnya untuk menerima dan menganut agama Islam (Poelinggomang, 2005: 133; Longi, dkk. 2001).

Keterangan masuknya Islam di Tanete didukung data yang terdapat dalam naskah klasik (manuskrip) milik Syamsuddin, yang berjudul: Iyanae Kitt $a^{\prime}$ Panssaengngi Asellengengnge ri Tanete, yang artinya: "setelah lima tahun lamanya Pette Palase-LaseE memerintah di Kerajaan tanete, datanglah seruan raja Gowa kepada raja Tanete untuk dating ke Kerajaan Gowa guna menerima Islam. Ketika itu seluruh orang Makas- sar telah dinyatakan masuk Islam. Setelah agama Islam diterima dengan baik oleh Petta Palase-LaseE, maka kembalilah beliau menyampaikan atau menyeruhkan kepada rakyatnya, dan juga termasuk raja Nepo" (Syamsuddin S, 1954: 41).

Dalam penyebaran agama Islam di pedalaman Sulawesi yang pada mulanya secara baik (damai) kemudian secara kekerasan oleh Raja Gowa Tallo, Kerajaan Tanete ikut membantunya, sekitar tahun $1608 \mathrm{M}$, seperti yang dikemukakan H.D. Mangemba, sebagai berikut: "Sultan Alauddin balik lagi ke Gowa dan belum cukup dua bulan, maka Raja Gowa ke Tanete untuk menyerang Soppeng. Orang-orang Lamuru dan orangorang Marioriawa menyerah kepada Raja Gowa dan masuk Is lam" ( Mangemba, 1956: 88).

Masuknya agama Islam di Tanete berkaitan dengan rancangan pemerintah Kerajaan Gowa yang menempatkan kerajaannya menjadi pusat syiar Islam di Sulawesi Selatan. Namun jauh sebelum Kerajaan Gowa mengadakan proses islamisasi, di Tanete telah lama ada ritualritual agama Islam lewat perdagangan maritim yang telah ada pada masa kepemimpinan La Tinulu Daeng Ngaseng dan diteruskan oleh pelanjutnya. Dimana dalam perdagangan tersebut banyak pedagang dari tanah Melayu, Johor, Minangkabau dan bahkan orang-orang jazirah Arab telah menjalin hubungan dagang dengan Tanete. Pedagang-pedagang tersebutlah yang banyak melakukan ritual agama Islam di Tanete yang sedikit banyaknya menjadi topik perbincangan diantara mereka. Sehingga agama Islam yang disosialisasikan Kerajaan Gowa kepada kerajaan Tanete bukanlah persoalan baru tetapi telah menjadi pemahaman yang lumrah dan telah lama dikenal lewat pedagang-pedagang (Mappangara, dkk. 2007: 19). 
Proses islamisasi di Tanete berlangsung dengan tertib dan damai. Hal itu berkaitan dengan metode penyiaran yang tidak memaksa rakyat dengan serta merta meninggalkan tatanan kulturalnya, tetapi dengan sikap persuasif mendorong mereka untuk mempelajari dan memahami ajaran agama. Itulah sebabnya hanya dua tahun dilakukan syiar Islam di Tanete, disebutkan bahwa seluruh rakyat Tanete telah menerima Islam. Atas kenyataan itu, raja menetapkan bahwa agama Islam menjadi agama resmi Kerajaan Agangnionjo pada tahun 1610. Disamping itu para pedagang muslim dan penguasa muslim senantiasa bersedia memberikan bantuan, baik penguasa di Sulawesi Selatan seperti Kerajaan Gowa, maupun penguasa dari kerajaan dimana para pedagang muslim yang mengunjungi atau menetap di kerajaan itu. Hal itu yang menyebabkan perdagangan berkembang sangat pesat karena pedagang muslim diterima dalam sistem pengembangan perdagangan dan syiar Islam serta melapangkan jaringan niaga dengan kerajaan yang berkembang di Nusantara (Mappangara, dkk. 2007: 19-20).

Kesepakatan Kerajaan Gowa dan Kerajaan Tanete untuk berkewajiban menyiarkan dan mengajak kerajaan lain untuk menerima dan menganut agama Islam. Kerajaan Tanete dimandatkan untuk mengajak Kerajaan Nepo menganut agama Islam. Pilihannya jatuh kepada Kerajaan Nepo sebab berkaitan dengan kedudukan kerajaan itu sebagai pemegang supremasi dan pengaruh kekuasaan terhadap kelompok konfederasi Malusetasi (Soreang, Bacokiki, Bojo, Palanro dan Nepo) dan konfederasi Ajataparang (Sidenreng, Rappang, Suppa, Sawitto, dan Alita). Pada sisi lain Kerajaan Nepo memiliki jalinan kekeluargaan pula dengan Tanete dan Soppeng. Oleh karena itu, ketika raja Tanete menawarkan agar Arung Nepo juga diserukan untuk menerima dan menganut agama Islam, ternyata syiar Islam itu diterima dengan baik oleh Arung Nepo dan menyatakan bersedia menjadi muslim. Kemudian Daeng Matepu mengajarkan syahadat dan ajaran Islam dan turut serta menyiarkannya kepada rakyat Nepo.

Apa yang direncanakan Kerajaan Gowa dan Kerajaan Tanete bahwa kalau Kerajaan Nepo mampu diislamkan maka akan mempermudah mengislamkan kerajaan lainnya termasuk TellumpocoE (Bone, Soppeng dan Wajo). Dimana Kerajaan Soppeng menerima Islam pada tahun 1609, menyusul Kerajaan wajo pada tahun 1610 dan juga Kerajaan Bone. Hal lain disebutkan bahwa proses islamisasi di Sulawesi Selatan pada awal perkembangannya di pusatkan di Makassar dan Tanete. Kenyataan itu berdampak pula kepada dua kerajaan tersebut menjadi pusat studi Islam. Pusat studi Islam di Kerajaan Gowa berpusat di Tallo. Pusat studi ini dikunjungi oleh utusan kerajaan dari kelompok TellumpocoE dan kerajaan-kerajaan yang berada di bagian selatan, seperti Bulobulo, Lamati dan Bantaeng. Sementara pusat studi Islam Tanete lebih banyak datang dari kerajaan yang tergabung dengan konfederasi Malusetasi dan konfederasi Ajataparang untuk mempedalam pengetahuan Islamnya.

Proses Islamisasi di Sulawesi selatan menunjukkan ada dua kerajaan yang menjadi pioneer syiar Islam, yaitu Kerajaan Makassar (Gowa-Tallo) dan Kerajaan Tanete. Kerajaan Makassar yang pertama kali menganjurkan proses islamisasi terhadap kerajaan-kerajaan di Sulawesi Selatan dan Kerajaan tanete tampil menjadi pendukung dan pelaksana islamisasi di kerajan-kerajaan yang tergolong dalam persekutuan Mallusetasi dan Ajataparang. Kenyataan itu berdampak pula dua kerajaan itu tampil menjadi pusat studi Islam. Pusat studi 
Islam di Kerajaan Makassar berpusat di Kerajaan Tallo. Pusat studi ini dikunjungi oleh utusan kerajaan dari TellumpoccoE dan kerajaan-kerajaan yang berada di bagian selatan, seperti BuloBulo, Lamatti, dan bantaeng. Sementara kerajaan-kerajaan yang masuk dalam persekutuan Mallusetasi dan Ajatapparang lebih memilih Tanete sebagai tempat memperdalam pengetahuan Islam. Itulah sebabnya dalam lontara Tanete dinyatakan bahwa "kalau bersamaan dipanggil (kerajaan-kerajaan Ajatappareng, Suppa, Soppeng, dan Tanete, oleh Nepo, pen). Hanya Tanete yang didatangi sebab Tanete yang mengajarkan Syahadat" (Musa, dkk. 1990: 111). Pernyataan ini menunjukkan bahwa pusat syiar islam ke kerajaan-kerajaan itu berpusat di Tanete (Poelinggomang: 2005: $54)$.

\section{Laponci (1603-1625): Pioneer Islam di Tanete}

Sudah menjadi metode umum dan sekaligus melegitimasi supremasi kulturnisasi seorang raja bahwa raja adalah pewakilan Dewata dalam melaksanakan kekuasaan di bumi, terlepas dari benar salahnya. Karena itu raja tampil menjadi pusat kultus masyarakat, baik pada periode sebelum Islam menjadi agama kerajaan maupun sesudahnya. Dalam hubungan itulah setiap pemegang kendali politik senantiasa berusaha berbuat yang terbaik bagi rakyatnya (Sahajuddin, 1010: 101-102). Sebagai masyarakat yang berada dalam pemerintahan monarchi, dimana raja adalah segalanya, ia diyakini tetesan dari atas (tomanurung), maka saat rajanya pindah keyakinan maka rakyatnya pun ikit pindah keyakinan. Demikian halnya dengan masyarakat kerajaan tanete pada saat itu, pada saat raja masuk Islam, maka rakyatnyapun masuk
Islam. Adapun raja yang menjadi pioner Islam di kerajaan tanete adalah La Ponci. La Ponci setelah diangkat menjadi raja, ia bergelar Petta Sugie (kaya). Konon raja inilah yang paling kaya dari sekian banyak raja sebelumnya. Pada masa raja Petta SugiE, kerajaan Tanete mengalami kemajuan yang pesat. Kemajuan itu dicapai berkat kerja keras dalam memajukan kegiatan perdagangan dan pemasaran produksi komuditas rakyatnya. Selain bergelar Petta SugiE, Petta Ponci pun bergelas Petta PalaselaseE. Ia digelar demikian karena ia mengebiri para lelaki penjaga permausirinya. Pengebirian itu dilakukan pada lelaki penjaga permaisurinya, karena ia khawatir bila para penjaga tersebut berbuat tidak senonoh kepada permaisurinya yang masih muda sementara dirinya sudah tua (Wawancara dengan Syarifuddin Daeng Tawang, Abdullah Karim, dan Makmun Badaruddin di Barru).

Setelah Petta Palase-LaseE memperdalam syariat islamnya di Sombaopu, beliau pun pulang untuk menyebarkan agama islam di negerinya. Dalam kegiatan syiar Islam itu raja Petta Palase-LaseE mengangkat seorang ulama, yaitu Daeng Matepu menjadi guru agamanya, dan sekaligus menjadi wakilnya dalam melakukan syiar Islam. Selain memiliki seorang ulama dalam kegiatan syiar Islam, raja juga giat mempererat jalinan hubungan dengan pedagang muslim yang telah lama menetap dinegerinya. Sehubungan dengan itu Petta Palase-LaseE mempersunting puteri raja Johor. Perkawinan itu terjadi ketika proses islamisasi sehingga hal itu menunjukkan sang raja ingin mempererat jalinan hubungan dengan pedang muslim di Tanete agar dapat ikut membantu dalam syiar Islam di kerajaannya dan juga di kerajaan tetangga lainnya.

Islam dimaknai sebuah proses historis yang diperankan oleh manusia 
penganutnya, atau sebuah gerak sejarah yang bertolak dari wahyu dan wahyu itu melahirkan tradisi. Sementara tradisi bagaikan sebua pohon yang akarakarnya tertanam melalui wahyu di dalam sifat Ilahi dan darinya tumbuh batang cabang-cabang sepanjang zaman (Nasr, 1994: 3). Maka dengan demikian proses islamisasi bukanlah persoalan yang sulit. Demikian masalah tempattempat syiar Islam di Sulawesi Selatan yang juga menempatkan Kerajaan Tanete sebagai tempat syiar Islam.

Hubungan Kerajaan Tanete sejak Dato GollaE dan penguasa Makassar telah lama tertanam sejak abad XVI dan kini hubungan antara kedua kerajaan ini sepakat dan berkewajiban menyiarkan dan mengajak raja Nepo untuk menerima dan menganut agama Islam. Pilihannya pada Kerajaan Nepo berkaitan dengan kedudukan Kerajaan Nepo dalam jaringannya terhadap kerajaan lain. Kerajaan Nepo adalah kerajaan yang memiliki supremasi dan pengaruh sosial-kultural serta kekuasaan terhadap kelompok konfederasi Malusetasi, dan kelompok konfederasi Ajatapparang. Kerajaan-kerajaan yang masuk dalam kelompok Malusetasi adalah Soreang, Bacukiki, Bojo, Palanro, dan Nepo. Sementara kelompok konfederasi Ajatapparang meliputi Sidenreng, Rappang, Suppa, Sawitto dan Alitta. Dua kelompok konfederasi tersebut dalam perkembangannya kemudian menjalin hubungan politik untuk saling membantu. Pada sisi lain penguasa Nepo memiliki jalinan kekeluargaan pula dengan Tanete dan Soppeng. Sementara penguasa Makassar mengembangkan tugas kepada raja Tanete untuk menawarkan kepada Arung Nepo agar juga diserukan untuk menerima dan menganut agama Islam (Sahajuddin, 2010: 101112).

Jaringan hubungan sosial-budaya yang menjadi dasar bagi Petta Palase
LaseE memilih untuk pertama-tama mengajak Arung Nepo menerima dan menganut agama Islam. Sebagai kerajaan yang memiliki hubungan kekerabatan inilah yang menjadi pertimbangannya bahwa jika karejaan itu telah menerima Islam menjadi agama kerajaan maka dapat mempermudah syiar Islam ke kerajaan-kerajaan lain yang bernaung dalam konfederasi Malusetasi dan Ajatapparang. Supremasi Kerajaan Nepo terhadap keuda konfederasi kerajaan tersebut sangat besar karena kerajaan-kerajaan itu memiliki pertalian kekeluargaan (hubungan kekerabatan).

Untuk tugas syiar Islam yang diemban oleh raja Kerajaan Tanete, Petta Palase LaseE kepada Kerajaan Nepo dibantu oleh mubaligh yang bernama Daeng Mattepu. Usaha syiar Islam itu diterima dengan baik oleh Arung Nepo dan menyatakan bersedia menjadi muslim. Sejak itu tugas selanjutnya diembankan kepada Daeng Mattepu untuk mengajarkan syahadat dan ajaran Islam lainnya kepada rakya Nepo. Model pengajarannya lazim disebut sistem dakwah islamiyah, yaitu suatu model pengajaran yang dilaksanakan secara umum dengan berpedoman pada syariat Islam. Dalam masyarakat Tanete, ulama pendakwah model ini disebut "guru lahiriah" (panrita lahereng). Penyebutan ini berawal ketika muncul dan berkembang aliran tarekat, khususnya tarekat Sattariyah dan ulama penganjurnya disebut "guru bathiniah" (panrita bathen).

Petta Palase LaseE dianggap berhasil sebagai penyiar Islam setelah Nepo menerima Islam dan menjadikannya agama kerajaan. Kerajaan-kerajaan lain yang berada dalam naungan dan supremasinya juga bersedia menerima Islam. Keberhasilan Petta Palase LaseE dalam pelaksanaan syiar Islam itu memberikan keuntungan kepada Kerajaan Gowa-Tallo yang bertekad menyiarkan 
Islam kepada kerajaan-kerajaan yang tergabung dalam TellupoccoE (Bone, Soppeng dan Wajo) yang pada awalnya menolak seruan itu (Gibson, 2010: 60). Perlu diketahui bahwa proses Islamisasi Kerajaan TellumpoccoE (Bone, Soppeng dan Wajo) tidak melalui jalan damai akan tetapi melalui peperangan yang dikenal dengan sebutan Mususelleng. Jalan ini ditempuh Kerajaan Gowa-Tallo mengingat kerajaan-kerajaan tersebut tidak mau menerima seruan raja Gowa untuk menerima agama Islam. Seruan itu didasarkan pada isi perjanjian yang telah disepakati jauh sebelumnya yang menyatakan "barang siapa yang menemukan suatu jalan baik, maka yang menemukan jalan baik itu harus memberitahukan kepada raja-raja lainnya yang terikat dengan perjanjian itu". Musu Selleng berlangsung kurang lebih empat tahun lamanya dan setelah itu barulah kerajaan-kerajaan di Tanah Bugis dapat dikuasai sepenuhnya oleh kerajaan Gowa-Tallo. Kerajaan-kerajaan Bugis lainnya yang tidak tergabung dengan TellumpoccoE menerima agama Islam sebagai agama resmi kerajaan tanpa melalui suatu peperangan. Dan kerajaan-kerajaan inilah yang membantu Kerajaan Gowa-Tallo memerangi Kerajaan TellumpoccoE sampai akhirnya menyerah kalah dan menerima agama Islam sebagai agama resmi kerajaan (Kila, 2010: 58-74; Amir, 2010: 75-94).

Oleh karena itu dengan bantuan laskar Sidenreng dan Nepo dengan kerajaan sekutunya, dan Kerajaan Luwu yang telah menerima Islam, maka Kerajaan Gowa-Tallo dapat memaksa Kerajaan Soppeng menerima Islam, maka Kerajaan Gowa-Tallo dapat memaksa Kerajaan Soppeng menerima Islam pada tahun 1609 dan menyusul Kerajaan Wajo tahun 1610, dan berikutnya tahun 1611, Kerajaan Bone juga berhasil menerima Islam (Sahajuddin, 2010: 101112).
Petta Pallase-laseE kemudian digantikan oleh Petta MatinroE ri Buliana (1625-1666). Pada masa pemerintahannya hubungan dengan kejaran Gowa mulai retak, karena ia membantu Arung Palaka meloloskan diri dari kejaran lasykar Gowa atas perintah Sultan Hasanuddin. Diriwayatkan, ketika Sultan Hasanuddin bersama-sama Karaeng Karunrung giat membangun benteng pertahanan untuk membendung serangan Belanda, atas perintah Karaeng Karunrung didatangkan 10.000 orang Bone ke Gowa untuk menggali sebuah parit yang memisahkan benteng Panakkukang dari dataran Gowa. Pekerjapekerja dari Bone itu di bawah pimpinan Tobala (Patunru, 1967: 41). Pekerjaan tersebut terlalu berat bagi orang Bone, sehingga timbullah ketidaksenangan mereka atas perlakuan orang-orang Gowa yang mengakibatkan orang-orang Bone di bawah pimpinan Tobala yang dibantu oleh Arung Palakka mengadakan pemberontakan terhadap Sultan Hasanuddin.

\section{SIMPULAN}

Ada beberapa kerajaan masa lampau yang pernah eksis di Kabupaten Barru. Kerajaan-kerajaan itu adalah kerajaan Nepo (Mallusetasi), Soppeng Riaja, Berru, dan Tanete. Selain kerajaankerajaan tersebut, terdapat pula kerajaan-kerajaan kecil yang merupakan kerajaan penyanggah yang disebut Lili. Adapun Lili tersebut antara lain: Bojo, Siddo, Kirukiru, Ajakkang, Balusu, dan lain-lain. Hubungan kerajaan-kerajaan yang pernah eksis pada masa lalu (khususnya Tanete) di Kabupaten Barru dengan kerajaan Gowa-Tallo terjadi sejak awal terbentuknya sampai kerajaan ini melebur ke dalam Negara Republik Indonesia. Antara Kerajaan Tanete dengan Kerajaan Makassar (Gowa- 
Tallo) mengalami pasang-surut. Masuknya Islam di Kerajaan Tanete melalui perantaraan Kerajaan Makassar, dimana pada saat Kerajaan Makassar menerima Islam dan menjadikannya agama Kerajaan, Raja Tanete pada saat itu (Petta SugiE) diundang ke Makassar untuk menerima langsung agama Islam. Masuknya Raja Tanete ke dalam agama Islam memosisikan kerajaan ini menjadi sekutu Raja Makassar untuk menyiarkan agama Islam ke daerah sekitarnya. Islam pertama kali diterima oleh Raja Tanete sekitar tahun 1608. Adapun raja yang menjadi pionir penyebar awal masuknya agama Islam di Kerajaaan Tanete adalah La Ponci yang bergelar Petta SugiE atau Petta Palase-LaseE yang dibantu seorang ulama yang bernama Daeng Matepu. Masuknya Raja Tanete yang terkenal kaya dan menjadi sekutu Raja Makassar dalam menyiarkan Islam menjadikan Kerajaan Tanete sebagai pusat studi Islam disamping Kerajaan Tallo pada masa itu.

\section{DAFTAR PUSTAKA}

Abdullah, Taufik. 1985. Sejarah Lokal di Indonesia. Yoyakarta: Gadjah Mada University Press.

Abdullah, Taufik. 1990. Sejarah Lokal Indonesia. Yogyakarta: Gadjah Mada University Press.

Amir, Muhammad. 2010. Islamisasi di Kerajaan Bone. Dalam Walasuji Jurnal Sejarah dan Budaya, Vol. 1, No. 1, Juni 2010, h. 75-94.

Departemen P dan K Seksi Kebudayaan Barru. 1983. Sejarah dan Adat Istiadat Daerah Tingkat II Kabupaten Barru. Barru: Dinas Pendidikan dan Kebudayaan Barru.

Gibson, Thomas. 2010. Narasi Islam dan Otoritas Di Asia Tenggara Abd Ke-16 Hingga Abd Ke-21. Makassar: Ininnawa.

HD Mangemba. 1956. Kenallah Sulawesi Selatan. Djakarta: Timun Masa.
Idham. 2012. Reaktualisasi Nilai Budaya Kemandaran. Makalah Disampaikan pada Seminar KKMSB (Kerukunan Keluarga Mandar Sulawesi Barat) Bekerja sama dengan Direktorat Jenderal Kesatuan Bangsa dan Politik Kementerian Dalam Negeri Republik Indonesia. Dengan Tema: "Peran Budaya Dalam Mengeliminir Konflik Horizontal Dalam Masyarakat", bertempat di Ruang Pola Kantor Bupati Majene pada tanggal 18 Juni 2012.

Kamaruddin, dkk. 1986. Lontarak Bilang Gowa-Tallo (terjemahan), Ujungpandang: Departemen Pendidikan dan Kebudayaan Republik Indonesia.

Kartodirdjo, Sartono. 1988. Pengantar Sejarah Indonesia Baru: 1500-1900, Dari Emporium Sampai Imperium jilid. Jakarta: Gramedia.

Kila, Syahrir. 2010. Islamisasi Kerajaan Tellumpoccoe. Dalam Walasuji Jurnal Sejarah dan Budaya, Vol. 1, No. 1, Juni 2010, h. 58-74.

Koro, Nasaruddin. 2005. Ayam Jantan Tanah Daeng: Siri' \& Pesse Dari Konflik Lokal ke Pertarungan Lintas Batas. Jakarta: Ajuara.

Longi, Syarief (ed). 2001. Kerajaan Agangnionjo (Tanete), Barru: Dinas P dan K Kabupaten Barru.

Mappangara, Suriadi, dkk. 2003. Sejarah Islam di Sulawesi Selatan. Makassar: Biro KAPP Sekretaris.

Mappangara, Suriadi, Nahdia Nur dan Sahajuddin. 2007. Laporan kompilasi dan analisis data Ensiklopedi Sejarah Barru periode awal sampai 1905. Barru: Dinas Kominfo Budpar Barru.

Mattulada. 1976. Agama Islam di Sulawesi Selatan, Ujungpandang: Leknas dan Universitas Hasanuddin. 1999. Sejarah, Masyarakat dan Kebudayaan Sulawesi Selatan. Makassar: Hasanuddin University Press.

Musa, H. And. Gaffar, dkk. 1990. Iyanae Poadaengngi Attoriolongnge ri Tanete (Sejarah Kebudayaan Tanete). Jakarta: Dirjen Kebudayaan Direktorat Sejarah dan Nilai Taradisional.

Nasr, Sayyed Hossein. 1994. Islam Tradisi di Tengah Kancah Dunia Modern. Bandung: Pustaka. 
Pertumbuhan dan Perkembangan Islam ... - Idham

Noordyun. 1972. Islamisasi Makssar (terjemahan). Jakarta: Lembaga Ilmu Pengetahuan Indonesia.

Patunru, A. Razak Daeng. 1967. Sejarah Gowa. Makassar: Yayasan Kebudayaan Sulselra.

Poelinggomang, Edward L. 2002. Makassar Abad XIX, Studi tentang Kebijakan Perdagangan Makassar. Jakarta: KPG (Kepustakaan Populer Gramedia). 2005. Sejarah Tanete Dari Agangnionjo Hingga Kabupaten Barru. Barru: Pemerintah Kabupaten Barru (belum terbit).

Poelinggomang, Edward L. dkk. 2004. Sejarah Sulawesi Selatan Jilid I, Makassar.

Rahman, Nurhayati dan Sri Sukesi Adiwimarta. 1999. Antologi Sastra Daerah Nusantara, Cerita Rakyat Suara Rakyat. Jakarta: Masyarakat Pernaskahan Nusantara - Yayasan Obor Indonesia.
Rahman, Nurhayati. 2008. Retna Kencana Colliq Pujie Arung Pancana Toa 18121876 Intelektual Penggerak Zaman. Makassar: La Galigi Press.

Sahajuddin. 2009. Bantaeang Pada Masa Kolonial Sampai Ekspedisi Militer Belanda 1905. Makassar: Departemen Kebudayaan dan Pariwisata Balai Pelestarian Sejarah dan Nilai Tradisional Makassar.

Sahajuddin. 2010. Proses Islamisasi di Kerajaan Tanete pada Abad XVII. Dalam Walasuji Jurnal Sejarah dan Budaya, Vol. 1, No. 1, Juni 2010, h. 101-112.

Syamsuddin S. 1954. Iyanae Kitta' Pannassaengngi Asellengengnge ri Tanete, Suatu Kajian Lontara". Tanete: Manuskrip.

Umar, H.A. Mu'in, dkk. 1985. Penulisan Sejarah Islam di Indonesia dalam Sorotan. Yogyakarta: Penerbitan Dua Dimensi. 